\title{
NOTES ON THE CURRENT DISCUSSION CONCERNING THE (FIRST) NAME OF THE FIRST HISTORICAL RULER OF THE PIAST STATE ${ }^{1}$
}

Keywords: Mieszko, Mbžıka, Piast dynasty, oldest Polish proper names

\begin{abstract}
After presenting the history of the problem, the present author focuses on three main underdiscussed or unsolved issues: (1) can Old Russian and Old Czech spellings suggesting a voiced spirant be reasonably explained away as secondary? (2) can a (near-) homonymous and potentially motivating appellative be found in the Polish or Slavic lexical traditions? (3) and why was the prince named in such way? The answer to the first question is negative, while the second one cannot for the moment be answered with certainty and needs further scrutiny. The author concludes that the name was ${ }^{\star} M b z ̌ b k a$ (as previously supposed by Fenikowski, Bańkowski, Mańczak, Sucharski and Witczak) and originated probably as a protective name aiming at preventing the child from ominous vision problems.
\end{abstract}

In 1947, Jan Otrębski expressed the view that Old Russian and Old Czech attestations of the name of the first historical ruler of Poland (today known as Mieszko the First, further on referred to as M. ${ }^{2}$ ) exclude the current reading Mieszka $\sim$ Mieszko ${ }^{3}$

1 The text was written in March and April 2019. English names of historical persons, chronicles, etc. were normalized according to the English Wikipedia. I am grateful to Rafał Szeptyński, Urszula Bijak and Sophia Tomasi for some logistic and linguistic help.

2 Or M., if the name is concerned.

3 For the history of the problem cf. e.g. Otrębski (1947: 95-103), Rospond (1955: 168-169), Fenikowski (1971: 231-233), Banasik (2013: 37-42). Attempts which do not recognize a wordinternal $-\check{z}$ - are as a rule not discussed in the present contribution. 
and force us to reconstruct a voiced spirant $\check{z}$ instead of $\check{s}$. Otrębski (1947: 94-112) saw in it a hypocoristic derivative Měžbko or Mižbko (as to 〈i in the first syllable, it is frequent in the oldest attestations dating from the $10^{\text {th }}-11^{\text {th }}$ centuries), ${ }^{4}$ derived from the second part of the compound ${ }^{\star} K a z i$-mérz $\sim{ }^{\star} K a z i$-mirz, encountered in the next generations of the Piast dynasty. He was inclined to assume up to six (!) different variants of the name (masculines in $-o,-a$ and perhaps $-\sigma$ combined with a twofold radical vocalism). Otrębski's proposal was criticized as it contradicts what was (and is) known about the derivation of hypocoristic names in Old Polish (they were almost universally derived from the first part of the compound, while - $g$ - or $-\check{z}$-did not function as hypocoristic suffixes, ${ }^{5} \mathrm{cf}$. Malec 1982: 18, 28-49). ${ }^{6}$ What is more, Otrębski (1950) somewhat later dissociated himself from his former view, proposing instead a borrowing from Old Prussian ${ }^{\star} M \bar{e} g i k \bar{a}$, which was an even worse solution (such a form, if adapted as late as in the $10^{\text {th }}$ century, would certainly not have yielded Proto-Polish ${ }^{\star} M b \check{z} b k a$ or $\left.{ }^{\star} M e \check{z} b k a\right)$.

In 1971, the "citizen scientist" Marian Fenikowski published a lengthy paper devoted to the name of $\mathrm{M}$. He opted for a reconstruction ${ }^{\star} M b \check{z} b k a$ (differing from Otrębski's one by radical vocalism and in part also by inflectional type), which in his opinion was the only one to reconcile the available evidence under a single denominator (a regular evolution $M b z ̌ b k a>M b z ̌ k a>M i e s z k a$, then Latinized to $\triangleleft$ Mesco -onis, hence the contemporary Mieszko). Curiously enough, Fenikowski completely disregarded the Old Russian evidence, focusing mainly on the oldest, philologically more or less ambiguous attestations found in Latin sources. In contrast to Otrębski, Fenikowski linked the etymological meaning of the name to the narrative presented by the chronicler Gallus Anonymus (Polish Gall Anonim), according to which M. was born blind and recovered from blindness at the age of seven. ${ }^{7}$ In Fenikowski's opinion, ${ }^{*} m b \check{z} b k a$ was an Old Polish appellative meaning 'visually impaired person' or a diminutive derivative thereof, belonging to the word family of Common Slavic ${ }^{*} m b \check{z} a t i \sim{ }^{*} m b \check{z} i t i$ mbži- (attested, among others, in the meanings 'to squint eyes', 'to blink', 'to have eyes closed, cf. ĖSSJa 21: 179, 181; while a well-established *' to have failing eyesight', contrary to Fenikowski, seems unattested).

Although Fenikowski's philological and linguistic argumentation objectively is to be assessed as quite professional, his remarkably exalted discourse and clearly

4 For a survey of historical attestations of the name see, e.g. Rospond (1955: 169-173), Fenikowski (1971: 233-236), Hertel (1980: 64-85).

5 Otrębski's reasoning was more complicated in detail. He assumed that a hypothetical ${ }^{*}$ Miromér was dissimilated to ${ }^{*}$ Mižoměr (allegedly reflected as early as in a Slavic person name attested in a Byzantine source in the $6^{\text {th }}$ century), and as a consequence ${ }^{*}$ miž- started to function as a sui generis hypocoristic substitute for ${ }^{*}-$ mir- $\sim^{*}$-mĕr-. This is, however, quite fantastic, as similar dissimilations are not thinkable of before a change $r^{j}>r^{z}$ had occurred. The latter, as is known, was not completed in Old Polish before the $12^{\text {th }}$ century.

6 The same applies to Banasik's (2013: 57-58) derivation Mir+jb+ko (sic!) > Miszko > Mieszko, which in addition disregards what is known about both the history of Polish $r z$ and the prehistory of the suffix - $k o$. As it seems, his paper was not reviewed for publication by a professional linguist specializing in the (pre)history of Polish.

It has to be stressed that the chronicler himself did not connect explicitly the meaning of M.'s name with the story he was telling. 
invented historical narratives he used to intermingle with analytic fragments of his work could not inspire confidence. These circumstances (as well as probably his lack of academic affiliation) can be held responsible for the fact that his proposal remained disregarded (or explicitly rejected) ${ }^{8}$ by both historians and linguists for almost twenty years (cf. Bańkowski 1989: 132; Mańczak 1997: 14).

Opinions started to change in the late eighties. In his paper on the names of the forefathers of Boleslaus the Brave, Bańkowski (1989: 132-134; cf. also 20oo: 235-236) fully endorsed Fenikowski's hypothesis, attaching particular importance to the unambiguous Old Russian attestations. Eight years later, Mańczak (1997) published a short, but enthusiastic communication devoted to Fenikowski's paper. Recently, Fenikowski/Bańkowski's account was backed up and elaborated on in some detail by Sucharski. ${ }^{9}$ The main thrust of Sucharski's (2015: 234-237) article is, in my opinion, his demonstration that the allegedly mysterious phrase qui primus nomine vocatus alio ( illo in an isolated copy), referred to M. by Gallus and previously interpreted in a number of ways, ${ }^{10}$ may simply have reflected a Medieval (Christian) Latin idiomatic expression meaning 'to be / become baptized' (M. was the first among his kin to be baptized). This phrase has thus to be removed from further discussion. Also Krzysztof T. Witczak (in an, as far as I know, unpublished paper read at a conference in Częstochowa in October 2016) adheres to this etymology of $M$.

Undertaking for a while the task of an advocatus diaboli, let us consider a possibility that the spellings $M e \check{z}(b) k a$ etc. do not reflect faithfully the form of the name as it

8 For example, Łowmiański (1986: 302) - who was not a professional linguist, but a historian - claimed that Mieżka was inappropriate/unclear ("niezrozumiały") as the name of a person (who in addition, let us note, lived a thousand years earlier). Hertel (1980: 82) argued that the Medieval Latin spelling was able to differentiate accurately between voiced and unvoiced spirants. This is obviously inconsistent with the common practice - note that both Dunaj (1975: 99) and Mycawka (2012: 91-95) refrained from discussing chronological aspects of the devoicing of spirants on the basis of spellings encountered in the $12^{\text {th }}-14^{\text {th }}$-century sources, evidently aware of their unreliability in this regard. Interestingly, Fenikowski (1971: 237-238), who also seemed to share such a view, was of the opinion that a voiced spirant must be reconstructed here because of the complete lack of spellings with $\langle-s s->$.

Earlier, Urbańczyk (1946: 117) declared that if as eminent philologist as Brückner had refrained from explaining away troublesome forms with $\langle-\bar{z}->$, he himself felt allowed to do so as well (!). In a later work (Urbańczyk 1952: 61), he argued that -š- must have been original because the chronicler Wincenty Kadłubek had identified the name with the appellative mieszka 'turbatio' < ‘měšska - as if he were unaware that Wincenty had lived approximately a century

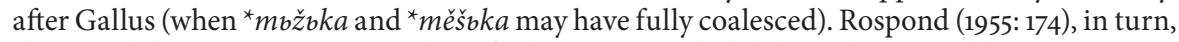
dismissed the reconstruction with - $\check{z}$ - for linguistic and philological reasons (!), in a not quite clear passage suggesting that the Old Russian form was modeled on the Old Czech hypercorrect spelling due to some (graphical?) German interference (!).

These quite hilarious attempts testify in fact to some sort of mental or emotional blockade which prevented the immediately post-war generation of Polish scholars from giving the data their proper due and taking a fresh look at the problem.

Recent opinions expressed by some historians (cf. Bogucki 2004; Urbańczyk 2012: 167-190; Jasiński 2013; Nowak 2016) indicate that for some reason they are unable or uninterested to penetrate into the linguistic essence of the issue.

9 His (Sucharski 2015: 239) derivation of the corrupted instr. form Mežbku(j)emb from ${ }^{\star} M e z ̌ b k o m b$ $u(j) e m s$ should be, however, replaced by that from ${ }^{\star} M e z ̌ b k o(j) u u(j) e m b$, as the name is otherwise inflected as an ${ }^{*}-\bar{a}$-stem in the Hypatian Chronicle. 
was used in Old Polish or Old Russian, but are due to some sort of hypercorrection. For example, if the devoicing of consonant clusters of the type ZT ( $Z$ - voiced spirant, $T$ - voiceless occlusive) in Old Polish predated a similar devoicing in Old Russian, ${ }^{11}$ it would be possible for speakers of the latter to adapt an Old Polish etymological cluster $\check{s} k$ as their own $\check{z}(b) k$.

This raises the question concerning the time the name was borrowed into Old Russian. Sucharski (2015: 239) thought that the borrowing may have taken place as early as in the $10^{\text {th }}$ or $11^{\text {th }}$ centuries, before the loss of weak yers in Proto-Polish. ${ }^{12}$ However, neither M. (†992) nor his grandson M. Lambert (†1034) were mentioned by names in Old Russian chronicles. The numerous attestations found in the Hypatian Chronicle refer to Duke M. the Old (born between 1122 and 1125, deceased in 1202), who was a son of Duke Boleslaus the Wry-mouthed. Between 1151 and 1154, he married a daughter of Duke Iziaslav of Kiev, and we can be confident that at least starting from that moment ${ }^{13}$ his name was in constant and continuous use at the Kiev court.

Scholars of Old Polish often assume that devoicing of medial clusters -DT- is attested as early as in the Bull of Gniezno (end of the $1^{\text {st }}$ half of the $12^{\text {th }}$ century), while the problem of devoicing of similar clusters of the type -ST-is considered insoluble in view of the generally recognized ambiguousness of spelling (cf. Dunaj 1975: 99). This view is based on Dunaj (1975: 98-99), who saw in the Bull two examples of devoicing, namely in the spellings 〈Datk〉 (person name) and 〈pretche〉 (lake name), both located in the northern part of Greater Poland or Cuyavia. Neither of these two examples is, however, probative.

As for 〈Datk〉, read D’ätk (or the like) and traced back to a proto-form ${ }^{\star} D e ́ d z k s$ : ${ }^{\star} d e \check{d} d z k z$ (: Standard Polish dziadek 'grandfather'), ${ }^{14}$ other possibilities can be suggested as well. Some Slavic languages have words covering a Common Slavic protoform * dětzkz (masculine ${ }^{*}-o$-stem), which are regarded as secondary, independently created singular forms of the feminine plural *dět $z k y$ 'children' (Lower Sorbian

${ }_{11}$ It should be kept in mind that just in the area where the name may reasonably have been borrowed (northwestern part of the Proto-Ukrainian linguistic territory, somewhere between the eastern limits of the Piast state and Kiev) no uniformization of such clusters with regard to voicedness took place at all (AUM 1 and AUM 2 do not even map it, as the area seems undifferentiated in this respect; for the reflexes of ${ }^{\star} l z z ̌ b k a \sim ?{ }^{*} l y z ̌ b k a$ see AUM 2: map 65). The same applies to adjacent dialects of southern Belarus (Blinava, Mjacelbskaja 1980: 50, 53-54).

12 Obviously, the fact that an Old Russian weak yer was written (or even pronounced) in the borrowed name does not imply that the borrowing must have taken place before the loss of weak yers in the donor language. It is a well-known fact that even adaptations of forms ending in consonants in the donor (e.g. Turkic) languages were supplied with final yers in Old Russian. As for the (inconsistent) presence of a medial yer in $M e z z(b) k a$, this case does not differ essentially from that of Lest(b)ko (the name of a Polish duke born as late as in the eighties of the $12^{\text {th }}$ century, and previously not used in the Piast dynasty). In what is now Ukraine weak yers were lost probably in the middle of the $12^{\text {th }}$ century (Žovtobrjux et al. 1979: 177-181; Ševelbov 2002: 309-317).

13 Nevertheless, note that the first mention of M. the Old in the Hypatian Chronicle refers to events of the year 1145 .

14 This and many other names attested in the Bull reflect the dialectal West Slavic loss of otherwise strong yers, sometimes referred to as Andersen's law or rule (cf. Andersen 1970). 
źétk, Slovene dẹtək, Church Slavic dětıkъ, cf. SP 3: 174, s.v. dětıky : dětıky). Furthermore, in Old Russian a nom. pl. form děti 'orators' is documented. Although Wojtyła-Świerzowska (in SP 3: 172, s.v. dětb 2.) interpreted it as a transformation of a nom. pl. ${ }^{*}$ dětrje ${ }^{*}-i$-stem masculine ${ }^{*} d \check{e}$ - $t$ b comparable with ${ }^{*} t a-t b$ 'thief') under the influence of collocated plural forms, I think that an ${ }^{\star}$-o-stem nomen agentis ${ }^{*}$ déts $\left(<{ }^{*} d^{h} \bar{e}-t o-\right)$ is more probable here. It is significant that another example of $\langle$-dat〉 ( $\langle$ Milodat $\rangle$ ) is found in the Bull, which can be interpreted in a similar manner (cf. Bańkowski 1986: 447). It would be perplexing if out of four cases of devoicing attested (cf. Dunaj 1975: 107) in a monument encompassing over 400 names no less than two contained the same morpheme ${ }^{\star} d e \check{d}-$.

As for $\left\langle\right.$ pretche,${ }^{15}$ its etymology assuming a possessive derivative from a hypocoristic (mutilated and derived) person name ${ }^{\star}$ Przedek (: Przedsław or the like, cf. recently NMPol 9: 291, s.v. Przedecz) is based on the unwarranted assumption that a voiced $d$ "reappearing" in later attestations of the place name (today Przedecz, cf. NMPol l.c.) is original. In fact, if the lake was situated in a territory where dialects conforming to Andersen's rule were spoken, the medial yer must have been lost in all case forms of its name, including even the gen. pl. (although it probably did not possess plural forms). The later form Przedecz must be thus considered as an innovation derived from Przetcz- which cannot give us clues as to the original phonetic shape of the cluster. So, ${ }^{\star}{ }^{\star}$ per-tzk-is conceivable as well.

Dunaj's (1975) next example chronologically is «Gethco (...) Gethconis〉 'Gedeon' (name of a bishop) stemming from an original manuscript of 1198, which can be considered as the first reliable case of a devoicing $d k>t k$. It can be concluded that devoicing started in the $2^{\text {nd }}$ half of the $12^{\text {th }}$ century, shortly (a century?) after the loss of medial weak yers, i.e. was contemporaneous with or even slightly later than the borrowing of $M$. into Old Russian. As for Old Czech, complete devoicing took place after the change $g>h$, as evidenced by isolated forms of the type lehký/lexki:/ $<{ }^{*} \log z k \bar{y}$ [not †lekký (as in Polish, where no $g>h$ took place)], thus not before the $13^{\text {th }}$ century (according to different sources, not earlier even than in the following one, cf. Lamprecht et al. 1977: 87-88). The Old Czech evidence for $\check{z}$ is, to all intents and purposes, less precious than the Old Russian one.

As is known, the oldest extant copy of the pertinent part of the Hypatian Chronicle dates from the beginning of the $15^{\text {th }}$ century and was prepared somewhere in the Pskov area. The protograph was compiled possibly in the $14^{\text {th }}$ century on the basis of several Western Ukrainian chronicles and digests dating from the $12^{\text {th }}-13^{\text {th }}$ centuries. However, if the text were copied in a traditional way, i.e. by a single scribe from manuscript to manuscript, a massive and consistent replacement of ${ }^{\star} M e s ̌ b k a$ of the protograph by Mežbka is not expected at all. It would be possible that the text was in fact dictated to scribes by a lector after the devoicing $\check{z} k>s ̌ k$, but in that case we would expect a series of non-etymological spellings, involving cases of both graphical

15 It should be noted that the combination «che s was used in the Bull to denote not only če, but also a single č (‘Bariche〉 'Barycz', cf. Bańkowski 1986: 443). A reading Pŕetč is thus equally probable as Pretče. 
voicing and devoicing, particularly if proper names and lexical archaisms (the correct spelling of which the scribes ignored) are concerned. This seems to be not the case, as the chronicle is not mentioned in the context of the beginnings of devoicing (Gorškova 1968: 141-142; Kolesov 1980: 158-171; Galinskaja 2009: 103-105).

As to the person name Køstjažko (= Kostjažko?) attested in the same chronicle,

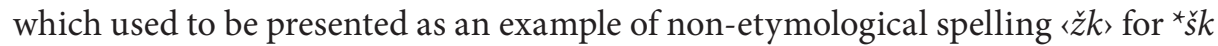
(cf. Rospond 1955: 174; Łowmiański 1986: 302, who both considered it as an untypical hypocoristic of Konstantinz), its etymology is far from obvious. In spite of Skulina (1974: 74), who also shared their view, it may well be derived from an appellative. Reflexes of kostjaga are attested in Russian dialects in several meanings derivable from 'bone' (kostb), cf. SRNG 15: 88, s.vv. kostjága 1. and 2., kostjážnik 1. and 2.).

Nowadays it can be stated that the issue of the exact structure of the name has been settled. Professionals finally realized (and accepted) that no real philological counter-evidence can be produced against the reconstruction $M b z ̌ b k a$ (which thereby has deserved the adjective "unchallenged"). ${ }^{16}$ What remains to be done is to justify the appearance of such a name within the anthroponomastic system of Proto-Polish.

A question can be asked if an appellative matching a protoform ${ }^{\star} M b z ̌ b k$ - has been preserved in related meanings in historical Slavic languages. Obviously, the complete lack of its traces on the appellative level would somewhat detract from the attractiveness of the theory defended here. Fenikowski (1971: 239; Bańkowski 1989: 132 who followed Fenikowski) quoted Polish mżek 'blind man buff (children's play)', which formally can be traced back to ${ }^{\star} m b z ̌ z k r$, differing from ${ }^{\star} m b z ̌ z k a$ only by inflectional type. Such a word is not found in Polish dictionaries, but closer scrutiny reveals that it must be an etymologically standardized spelling of $\langle m r z e k\rangle$ as attested in the dictionary by Michał Abraham Trotz (column 872):17 "Mrzekg a. zmruzek die blinde Kuh, ein Kinder-Spiel. collin maillard un jeu d'enfant". Along with it, Trotz gives the form $m r z y k$, which is also attested (as $m \dot{z} y k$ ) by other sources, both historically and dialectally (Linde 2: 176, s.v. mżé́; SW 2: 1089; Karł. 3: 209). It functions as contemporary Polish surname as well (cf. SNazw 6: 515) and has counterparts in other Slavic languages (e.g. Czech $m z ̌ i k$, cf. ĖSSJa 21: 180, s.v. $\left.{ }^{*} m b z ̌ i k a /{ }^{*} m b z ̌ i k r ~ I\right)$. Both ${ }^{\star} m b z ̌ b k r$ and ${ }^{\star} m b z ̌ z k a$ can easily be explained as nomina agentis ${ }^{18}$ formed from the verb *mbžati $>$ Polish mżeć.

16 In other words, Łuczyński (2015: 74) clearly misrepresented the existing state of art when he claimed that the only two proposals that stood up criticism were those assuming a proto-form ${ }^{\star} M E \check{s} b k z$.

17 Trotz' dictionary was compiled in the $1^{\text {st }}$ half of the $18^{\text {th }}$ century and published between 1744 (French-German-Polish) and 1772 (German-Polish). Its author, stemming from a Lutheran family of German descent, was born (probably between 1689 and 1703) and raised in Warsaw. He died in 1769. Apart from lexemes known to Trotz himself, the $1^{\text {st }}$ edition of the dictionary contains words found in some printed texts (by other authors) perused by him as well as some words supplied by Trotz' collaborator Józef Andrzej Załuski (Hrabec, Pepłowski 1963: 211).

18 For this function of the suffixes, cf. e.g. Sławski in SP 1: 93, 94; for Old Polish, cf. Kleszczowa (1998: 92). The etymological meaning may thus have been 'who squints his / her eyes', whence secondary meanings 'child closing his/her eyes when playing blind man buff' (and 'blind man buff' in general) and *'person suffering from photophobia'. 
Unfortunately, Trotz'〈Mrzek $>$ must be handled with extreme caution, as it can be suspected of being a result of hypercorrect standardization of its more reliably attested variant $m r z y k$. As is known, in the $18^{\text {th }}$ century the vowel é continuing a former long $\bar{e}$ started to coalesce with $y$ in some parts of the Polish linguistic territory (cf. Klemensiewicz et al. 1965: 86-89). A rare, non-transparent (cf. its non-syllabic root $m \dot{z}$-) lexeme containing $y$ may thus have been standardized with é. Trotz, in his turn, noted both $e$ and é (which he probably did perceive in his own Mazovianbased idiolect as a vowel distinct from $y$ ) as $\langle e\rangle$. Mżek is somewhat supported by the surname Miezek (SNazw 6: 345, having become extinct in the course of the $2 \mathrm{O}^{\text {th }}$ century; $<{ }^{*}$ Mieże ${ }^{19}$ ?), which however is not characteristic enough to exclude other possible etymological explanations. A more appreciable argument would certainly be a semantically passing reflex of ${ }^{*} m b z ̌ b k$ - preserved in a Slavic dialect which keeps ${ }^{\star} i$ and the strong ${ }^{\star} b$ apart. A thorough perusal of hundreds of dialectal and historical dictionaries available must, however, remain a task for the future.

Another problem which awaits further discussion are circumstances in which the name was given. Fenikowski (1971: 243-244) devoted a chapter of his article to justify his view that a spontaneous recovery from blindness as narrated by the chronicler is nevertheless a plausible scenario. When $\mathrm{M}$. unexpectedly had recovered, the nickname 'the blind' ('Ślepotka') given to him by the folk was declared, as bene ominatum nomen, M.'s official and only name by his father (sic!). Also Bańkowski (1989: 132, 133) and Sucharski (2015: 237) seemed to believe that the young prince may temporarily have suffered from a kind of sight-related disorder. Bańkowski suggested that after his recovery $M$. considered his earlier "nickname" as a good omen and refused to use his other names (if he had any).

I am highly skeptical about that. As far as one knows, people of the $10^{\text {th }}$ century were unable to successfully cure such illnesses, while a spontaneous recovery is always a very unusual event. If $\mathrm{M}$. had experienced sight problems, this would have radically constrained his possibilities of competing successfully with his rivals (for example, his chances of being assassinated would have been risen drastically). Taking this into account, I would like to suggest another possibility. In my opinion, ${ }^{\star} M b z ̌ b k a$ may have been a kind of protective name right from the start, i.e. an expression used normally to designate a visually impaired person given to the child by his parents to prevent the danger of him falling $i l l .{ }^{20}$ It can be hypothesized that a child of M.'s parents (probably M.'s close sibling) ${ }^{21}$ was born (or subsequently fell) ill, whereas M. himself was spared such a handicap. ${ }^{22}$ He was aware of all that and,

19 Taken formalistically, mieżek given by Fenikowski (1971: 239) appears to be a ghost-word. Most probably, it was Fenikowski's reconstruction founded on the presumption that an Early Polish alternating paradigm mżek ${ }^{\star}$ mieżka must have split into more regular mżek mżeka on the one hand and ${ }^{\star}$ mieżek ${ }^{*}$ mieżka, on the other.

20 For similar nominations, cf. e.g. Budziszewska (1989, with further references).

${ }^{21}$ It should be borne in mind that M.'s father was pagan and may have had more than one wife as well as many children.

22 Banasik (2013: 45) objected that if M. was born blind, there was no reason in giving him a name protecting from blindness. However, the times when historians credited to anything told by ancient chroniclers unless it overtly fell into the category of phantasm, are far gone-by. 
as a superstitious person, stuck to this name throughout his life, using his given name upon having been baptized strictly only upon official occasions. ${ }^{23}$ It should be noted that a brother of M. who in 972 defeated invader troops led by Margrave Hodo at 〈Cidini〉 bore the name 〈Cidebure〉 (Thietmar, Latin abl. sg. form), convincingly interpreted as ${ }^{\star}$ Soděborz (Witczak 1992), ${ }^{24}$ thus a typical Slavic compound person name. It has to be reckoned with that the chronicler, who, for all we know (cf. recently Labuda 2006), was not a native speaker of a Slavic dialect and was compelled to communicate at the Piast court in Latin or in his imperfect variety of Proto-Polish as a learned foreign ${ }^{25}$ language, was given an explanation of the meaning of the duke name (which at the end of the $11^{\text {th }}$ century may still have been transparent to some inhabitants of Greater Poland), but did not grasp it properly. It is also possible that the communicated meaning of the name $M$. had inspired him with the invention of a quite fanciful story he finally wrote down. At any rate, Gallus is hardly expected to have presented to the educated Christian reader (for whom his chronicle was meant) a story in which the choice of the name for the dynasty's founder was motivated by some pagan superstition of his parents (cf. also Lisiecki 2013: 135-136).

\section{References}

AUM 1 = Atlas ukrajinsbkoji movy. [vol. 1: Polissja, serednja Naddniprjanščyna i sumižni zemli]. 1984. Kyjiv.

AUM 2 = Atlas ukrajinsıkoji movy. [vol. 2: Volynı, Naddnistrjanščyna, Zakarpattja i sumižni zemli]. 1988. Kyjiv.

ÈSSJa 21 = Ėtimologičeskij slovar' slavjanskich jazykov. Praslavjanskij leksičeskij fond. [vol. 21: ${ }^{*}$ morskovatzjo - ${ }^{*}$ nadějonzjb]. 1994. Moskva.

Karł. 3 = Karłowicz J. 1903. Słownik gwar polskich. [vol. 3: L-O]. Kraków.

I assume that the name may have been chosen for M. even before his birth, and the fact that he was born seeing was not sufficient to change this decision. People ever knew that even mature persons could lose sight.

23 I mean hereby the famous Dagome iudex digest, where M. is evidently referred to as $\langle$ Dagomer. As Witczak (1995) suggested, this might be a somewhat distorted form of his baptism name Tagomirz (or Tagomérz) he obtained after Duke of Stodorans Tagomir (who may have been M.'s godfather at his baptism of 966). Later Witczak (2016) pointed out that the day and month of the death of a mysterious duke ‘ $(\mathrm{Ob}$. $)$ Thugumir $(\mathrm{dux})$ 〉 as given in the Möllenbeck necrology (May, $25^{\text {th }}$ ) fully agree with those given for M.'s death by the chronicler Thietmar. However, the statistical calculations presented there (Witczak 2016: 46, ftn. 27) were probably based on the erroneous assumption that also the year agrees. In fact, we are dealing here with a classical example of the so-called "birthday problem" (the probability value of the event that 〈Thugumer and $\mathrm{M}$. were two different persons exceeds 0.5).

The recent proposal by Banasik (2013): Drogomir, otherwise unattested as ducal name, subsequently distorted as Dagome, is not credible.

24 This name has been adapted by the Polish historical tradition as Czcibor (or Ścibor). Some Polish linguists tried to justify this reconstruction on a scientific background ( ${ }^{\star} \check{C}_{b s t i b o r z}$ ). Weak points of such an approach were thoroughly recapitulated by Witczak (1992: 125-126). The most recent proposal by Łuczyński (2016): Sieciebor < *Sětěborz cannot be considered as superior to Witczak's one for obvious formal reasons.

25 And fairly distant from languages he was fluent in. 
Linde 2 S Słownik języka polskiego przez M. Samuela Bogumiła Linde. [vol. 2, part 1: M-O]. 1809. Warszawa.

NMPol 9 = Nazwy miejscowe Polski. Historia-pochodzenie-zmiany. [vol. 9: Pn-Q]. 2013. Kraków.

SNazw 6 = Rymut K. (ed.). 1993. Słownik nazwisk współcześnie w Polsce używanych. [vol. 6 : Ł-N]. Kraków.

SP $1=$ Sławski F. (ed.). 1974. Słownik prasłowiański. [vol. 1: A-B]. Wrocław, Warszawa, Kraków, Gdańsk.

SP $3=$ Sławski F. (ed.). 1979. Słownik prasłowiański. [vol. 3: Davbnz-Dobbrati]. Wrocław, Warszawa, Kraków, Gdańsk.

SRNG 15 = Slovar' russkix narodnyx govorov. [vol. 15: Kortusy-Kudeljuški]. 1979. Leningrad.

SW 2 S Słownik języka polskiego Jana Karłowicza, Adama Kryńskiego $i$ Władysława Niedźwieckiego [= Słownik warszawski]. [vol. 2: H-M]. 1902. Warszawa.

Trotz = Nowydykcyonarz to iest mownikpolsko-niemiecko-francuski (...) przez Michała Abrahama Troca, warszawianina, w Lipsku (...), MDCCLXIV [1764].

Andersen H. 1970. Kashubian dobëtk 'dobytek' and its kind. - Welt der Slaven 15: 61-76.

Banasik W. 2013. Dagome a Mieszko. - Slavia Antiqua 54: 21-60.

Bańkowski A. 1986. Dyskusyjne interpretacje staropolskich nazw osobowych w „Bulli Gnieźnieńskiej”. - Prace Filologiczne 33: 441-450.

Bańkowski A. 1989. Imiona przodków Bolesława Chrobrego u Galla Anonima. Rozważania etymologiczne. - Onomastica 34: 103-138.

Bańkowski A. 2000. Etymologiczny słownik języka polskiego. [vol. 2: L-P]. Warszawa.

Blinava Ė., Mjacelıskaja E. 1980. Belaruskaja dyjalektalohija. Minsk.

Bogucki A. 2004. Kilka uwag o imieniu Mieszka I. - Kuczyński S.K. (ed.). Społeczeństwo Polski średniowiecznej. Zbiór studiów 10. Warszawa: 9-18.

Budziszewska W. 1989. Imiona ochronne Słowian bałkańskich. - Onomastica 34: 237-244.

Dunaj B. 1975. Język polski najstarszej doby piśmiennej (XII-XIII w.). Kraków.

Fenikowski M. 1971. Polonia antiquissima restituta. O właściwą postać imienia Mieszko. Poradnik Jezzkkowy [facs.] 4: 231-245.

Galinskaja E.A. 2009. Istoričeskaja fonetika russkogo jazyka. [2 ${ }^{\text {nd }}$ edition]. Moskva.

Gorškova K.V. 1968. Očerki istoričeskoj dialektologii severnoj Rusi (po dannym istoričeskoj fonologii). Moskva.

Hertel J. 1980. Imiennictwo dynastii piastowskiej we wczesnym średniowieczu. Warszawa, Poznań, Toruń.

Hrabec S., Pepłowski F. 1963. Wiadomości o autorach i dziełach cytowanych w Słowniku Lindego. Warszawa.

Jasiński T. 2013. Mieszko - rozniecaj sławę! - Focus Historia [facs.] 6: 47-48.

Klemensiewicz Z., Lehr-Spławiński T., Urbańczyk S. 1965. Gramatyka historyczna języka polskiego. [ $2^{\text {nd }}$ edition]. Warszawa.

Kleszczowa K. 1998. Staropolskie kategorie słowotwórcze i ich perspektywiczna ewolucja. Rzeczowniki. Katowice.

Kolesov V.V. 1980. Istoričeskaja fonetika russkogo jazyka. Moskva.

Labuda G. 2006. Zamiana Galla-Anonima, autora pierwszej „Kroniki dziejów polskich”, na Anonima-Wenecjanina. - Studia Źródłoznawcze 44: 117-125.

Lamprecht A., Šlosar D., Bauer J. 1977. Historický vývoj češtiny. Praha.

Lisiecki M. 2013. Kronika Polska Galla Anonima w kontekście kształtowania się polskiej świadomości narodowej. - Sprawy Narodowościowe. Seria nowa 42: 131-142. 
Łowmiański H. 1986. Studia nad dziejami Słowiańszczyzny, Polski i Rusi w wiekach średnich. Poznań.

Łuczyński M. 2015. Nazwy własne w „Dagome iudex”. - Prace Językoznawcze / Papers in Linguistics [Olsztyn] 17.2: 69-94.

Łuczyński M. 2016. Gdzie walczył brat Mieszka I i jak miał na imię? - LingVaria 11.2: 157-164. Malec M. 1982. Staropolskie skrócone nazwy osobowe od imion dwuczłonowych. Wrocław, Warszawa, Kraków, Gdańsk, Łódź.

Mańczak W. 1997. O imieniu pierwszego władcy Polski. - Sprawozdania PAU 61 [1998]: 12-14. Mycawka M. 2012. Język polski XIV wieku. Wybrane zagadnienia. Kraków.

Nowak P. 2016. [rev. of Sucharski 2015]. - Studia Źródłoznawcze 54: 231.

Otrębski J. 1947. Imiona pierwszej chrześcijańskiej pary książęcej w Polsce. - Slavia Occidentalis 18 [1939-1947]: 85-125.

Otrębski J. 1950. Miscellanées onomastiques. 4. L'origine du nom "Mieszko". - Lingua Posnaniensis 2: 74-79.

Rospond S. 1955. Uwagi polemiczne o Mieszku, Masławie i Dąbrówce. - Onomastica 1: 168-185. Ševelıov Ju. 2002. Istorična fonolohija ukrajinsbkoji movy. Xarkiv.

Skulina T. 1974. Staroruskie imiennictwo osobowe. [vol. 2]. Wrocław, Warszawa, Kraków, Gdańsk.

Sucharski R.A. 2015. Jeszcze raz w kwestii imienia pierwszego historycznego władcy Polski. - Roczniki Historyczne 122.2: 233-244.

Urbańczyk P. 2012. Mieszko Pierwszy Tajemniczy. Toruń.

Urbańczyk S. 1946. O imię pierwszego historycznego księcia Polski. - Inter Arma. Zbiór prac ofiarowanych prof. Kazimierzowi Nitschowi w siedemdziesiąta rocznice urodzin (1. II. 1944) przez przyjaciół, uczniów i kolegów. Kraków: 107-117.

Urbańczyk S. 1952. Dwa zagadkowe imiona (Mieszko i Dąbrówka). - Slavia Antiqua 3 [19511952]: 52-72.

Witczak K.T. 1992. Z antroponimii piastowskiej: Zdziebor (nie Czcibor), brat Mieszka I. Onomastica 36: 123-132.

Witczak K.T. 1995. Polonia Antiqua. Głos w dyskusji nad imieniem chrzestnym Mieszka I. - Biuletyn Polskiego Towarzystwa Językoznawczego 51: 107-116.

Witczak K.T. 2016. Kto był ojcem chrzestnym Mieszka I? - Wróbel A., Piasta A. (eds.). 1050-lecie Chrztu Polski w wymiarze ogólnopolskim i regionalnym. Piotrków Trybunalski, Tomaszów Mazowiecki: 35-49.

Žovtobrjux M.A., Rusanivbskyj V.M., Skljarenko V.H. 1979. Istorija ukrajinskoji movy. Fonetyka. Kyjiv. 